\title{
Regiōes-províncias na Guerra da Tríplice Aliança
}

\author{
Cesar Augusto Barcellos Guazzelli
}

\section{Introdução}

Tem sido consenso entre os historiadores o papel representado pelos Estados nacionais no desenvolvimento universal do capitalismo, o que se deu de forma desigual e combinada, definindo aquelas potências centrais exportadoras de manufaturados e mais tarde capitais, e os países periféricos destinados ao fornecimento de matérias-primas. A organização destes Estados desencadeada em fins do século XVIII trouxe consequências econômicas, sociais, políticas e culturais que ainda perduram, pois isto implicava construir identidades nacionais, e este processo teve uma longa trajetória. ${ }^{1}$

$\mathrm{Na}$ América Latina, a formação dos Estados nacionais nas ruínas dos impérios coloniais apresentou grandes dificuldades, tais como as disputas entre setores exportadores e não exportadores, os conflitos entre oligarquias regionais, os temores de las clases peligrosas, problemas étnicos e religiosos, entre tantos. As atuais naçôes latino-americanas não foram, portanto, resultado de "vocaçōes" previamente estabelecidas, mas o resultado de um processo histórico muito complexo, cujos principais aspectos se desenvolveram ao longo do século XIX.

Tem sido comum a generalização de que um dos fatores capazes de favorecer a formação de uma identidade nacional é a formulação de um inimigo externo: se uma identidade só se constrói a partir de uma alteridade - ou seja, quando "nós" adquire significado ao ser oposto a "outros" -, uma guerra externa facilitaria esta condição. Assim, para a Confederação Argentina que atravessara períodos crônicos de guerra civil de 1810 a 1862, ou para o Império do Brasil com o longo ciclo de insurreiçóes conhecidas como Rebeliōes Regenciais, não estando ainda resolvidas as assimetrias entre as distintas regiōes, a guerra poderia catalisar a desejada união nacional. ${ }^{2}$ Porém, o exame da chamada Guerra da Tríplice Aliança - ou Guerra do Paraguai - não assegura essa hipótese; diversos conflitos internos dos países envolvidos, de alguma forma recrudesceram com a guerra no espaço platino, que teve diferentes implicações para os países envolvidos: a Argentina enfrentou graves problemas, nas províncias do litoral ${ }^{3}$ e nas do noroeste; o Brasil, uma vez mais arcava com os distúrbios dos rio-grandenses na fronteira; e no Uruguai acirraramse as disputas entre blancos e colorados, retardando ainda mais sua organização institucional.

A hipótese de que a Guerra do Paraguai não foi um fator de consolidação daquelas naçõos que compuseram a Tríplice Aliança obriga à formulação de outra questão: quais seriam as entidades políticas de fato na América platina, e em que medida a guerra a um inimigo externo mantinha ou mesmo reforçava essas identidades regionais em contrapartida a uma unidade política nacional. Os eventuais problemas enfrentados na Confederação e no Império diziam respeito às respectivas províncias, e é importante tratar de seu próprio processo de construção, e de que forma as identidades provinciais foram empecilhos à formação das identidades nacionais.

Para identificar com mais precisão os agentes políticos da questão nacional torna-se fundamental o conceito de "região-província". A queda dos impérios coloniais ibéricos não foi sucedida imediatamente pelos Estados nacionais, mas pelas unidades políticas que com um mínimo de organização social eram capazes de garantir as atividades produtivas e a ordem pública, através dos seus caudilhos. ${ }^{4}$ No Prata, as cidades coloniais nuclearam essas "regiōes-províncias", articuladas pelos respectivos produtores - quase sempre criadores e estancieiros -, resistindo aos grupos exportadores que tentavam organizar Estados centralizados para suas articulaçóes com o mercado externo. A bandeira do federalismo resulta do entendimento que os caudilhos tinham em relação ao Estado nacional, e refletia os anseios que tinham por autonomia política. 
Nestas lutas pelo poder, os caudilhos provincianos às vezes promoviam alianças com os de outras "regiōes-províncias", formando algumas ligas frouxas e instáveis. Desta maneira, o século XIX foi marcado pelas guerras entre distintas "regiões-províncias", entre setores que buscavam hegemonia no interior de algumas delas, e pela recusa dos projetos centralizadores ou unitários. A Guerra do Paraguai parece mais um corolário dessas lutas no processo de formação dos Estados nacionais, não tendo sido o fator de coesão interna que buscavam os projetos centralizadores.

O objetivo do texto é destacar as principais incidências nas "regiōes-províncias" diretamente envolvidas na Guerra da Tríplice Aliança, e os principais efeitos que ela trouxe para as mesmas. Inicialmente serão tratados os problemas apresentados pela Confederação Argentina, nas províncias do litoral e do noroeste, que comprometeram a pretensão do presidente Mitre em terminar seu mandato com uma nação consolidada. Não independente das questôes argentinas, o Uruguai também esteve na raiz da grande conflagração, quando o colorado Flores, que se impôs militarmente aos blancos com o apoio aberto da Confederação e do Império, tornou-se um refém dos seus poderosos aliados. Quanto ao Brasil, serão examinadas as questôes relativas ao Rio Grande do Sul, aquela província mais diretamente envolvida pela Guerra do Paraguai.

\section{Confederação Argentina: entre centralismo e federação}

\subsection{O litoral antes da Guerra do Paraguai}

Na década de 1830, a Confederação Argentina, apesar dos esforços de Rosas, o governador de Buenos Aires, passou por diversos problemas nas províncias do litoral. Destacou-se Corrientes, com a disputa entre o governador Pedro Ferré, defensor de uma política protecionista contra o livre-câmbio proposto pelo ministro Roxas y Patrón de Buenos Aires. ${ }^{5}$ Em 1838 houve a guerra desta província contra Rosas, com a derrota dos correntinos. Mas, no início dos anos 40, Pedro Ferré buscou auxílio nos unitários Lavalle e Maria Paz, para uma nova guerra contra Buenos Aires. Desta época são os artigos adicionais ao Tratado de Corrientes com o Estado Oriental, presidido pelo colorado Rivera em 1840, ${ }^{6}$ o Tratado de Corrientes com a República Rio-Grandense em janeiro de 1842,7 e o Convênio de Paysandu, reunindo as províncias argentinas de Corrientes, Entre Rios e Santa Fé, o Estado Oriental e a República Rio-Grandense. ${ }^{8}$

A derrota de Rivera em fins de 1842 frente à Confederação trouxe a guerra para as portas de Montevidéu, com a invasão da Banda Oriental pelo exército blanco de Oribe, isolando Corrientes e submetendo-a ao assédio de Urquiza, caudilho que retomara Entre Rios para o elenco das províncias tuteladas por Rosas. Iniciaram-se então as negociações de Corrientes com o Paraguai; em março de 1845 o governador correntino Madariaga desafiava os entrerrianos de Urquiza, contando com o auxílio de cinco mil paraguaios sob o comando de Francisco Solano López. As vitórias de Urquiza contra Rivera e Madariaga obrigaram Corrientes a estabelecer um acordo com os vencedores.

A intervenção paraguaia ao lado de Corrientes, "fue prematura, puesto que Paraguay aún no poseía una fuerza militar independiente", e teria sido este malogro o que "impulsó a López a modernizar su pais". Fiador da paz, Urquiza tornara-se o principal caudilho do litoral e Madariaga alentava-o com a possibilidade de um acordo entre Corrientes e Entre Rios que se estendesse ao Paraguai. Em outubro de 1846 o Tratado Corrientes-Entre Rios estabelecia a neutralidade em relação à guerra movida entre a Confederação Argentina e o Estado Oriental de Rivera, dava a Urquiza a direção dos assuntos externos, e aos correntinos, a intermediação de uma aliança com o Paraguai. ${ }^{10}$ Uma semana depois, Madariaga escrevia a Carlos Antonio López sobre a insatisfação das províncias com Rosas, e do papel relevante que assumia Corrientes para o comércio do Paraguai com o Brasil, burlando a alfândega de Buenos Aires. ${ }^{11}$

Ainda em outubro de 1846, López firmou um tratado com Corrientes, estabelecendo relações comerciais, ressaltando a posição do Paraguai enquanto Estado soberano. ${ }^{12}$ Em fins do ano seguinte, os correntinos, não conseguindo a adesão de Urquiza para uma ruptura com Rosas, entraram em conflito com Entre Rios, motivando mais uma vez a entrada de uma força militar paraguaia que ocupou o ter- 
ritório de Misiones. ${ }^{13}$ Nesta passagem, os paraguaios adquiriram reses e armas em São Borja, motivando queixas de Rosas através do seu chanceler Tomás Guido, pedindo punição para "as autoridades subalternas limítrofes com a província de Corrientes". ${ }^{14}$

Iniciava-se um período sem conflitos em Entre Rios, o que estimulou seu crescimento econômico e reaçôes contra a hegemonia de Buenos Aires. Formalmente fiel a Rosas e apoiando a campanha de seus aliados blancos na Banda Oriental, Urquiza mantinha sua intimidade com Corrientes e as possibilidades de alianças com o Paraguai. A navegação dos rios da bacia do Rio da Prata, pretendida pelas potências europeias, pelo Brasil e pelo Paraguai, e que era negada por Rosas, passava a interessar Urquiza, à testa de uma província próspera, mas fechada ao mercado externo. Assim, em 1851, ele apoiou o Brasil na intervenção contra os blancos de Oribe: no Convênio de Aliança assinado em 24 de agosto, os colorados, o Império e Entre Rios comprometiam-se a "libertar" a campanha oriental e abrir a navegação dos rios; ao tratado foi incorporada Corrientes em novembro, e o Paraguai em dezembro do mesmo ano. ${ }^{15}$

No ano seguinte, com o apoio do Império, Urquiza derrotou Rosas e se converteu na principal liderança da Confederação. Iniciava-se mais uma tentativa federal de organizar a Argentina, que uma vez mais fracassou pelas dificuldades em submeter Buenos Aires: tentando fazer Entre Rios o centro da Confederação, Urquiza provocou a secessão dos porteños; no final dos anos 50, houve uma guerra, com vitória da Confederação. A disputa durou até 1861, quando os porteños, com o apoio de Córdoba, Tucumán, Santiago, Salta e Jujuy, fizeram nova guerra a Urquiza que liderava o litoral - Corrientes, Santa Fé e Entre Rios -, além de La Rioja, Catamarca e Mendoza. Urquiza foi derrotado por Bartolomé Mitre, governador de Buenos Aires. Com o Convenio de Paz entre Mitre e Urquiza, a Confederação adotou de vez o projeto unitário sob o comando e controle de Buenos Aires. ${ }^{16}$

$\mathrm{O}$ agora presidente Mitre articulou uma união nacional cooptando os caudilhos provincianos pela adoção de medidas econômicas e políticas que lhes foram favoráveis. As primeiras foram a nacionalização dos direitos aduaneiros do porto de Buenos Aires - o que para algumas províncias era um enorme aumento de para suas rendas - e a incorporação das dívidas provincianas pelo Estado nacional; já as principais benesses políticas incluíam representação parlamentar das províncias e a preservação de suas autonomias internas. Mitre obteve assim um grande acordo que inaugurava o Estado nacional na Confederação, tendo a colaboração total de Urquiza, que passaria a tratar somente dos assuntos de Entre Rios.

Em 1862, a única oposição militar que enfrentou foi do caudilho de La Rioja, Angel Vicente Peñaloza, que tinha uma larga trajetória de lutas contra Buenos Aires. Peñaloza - El Chacho - tinha a oposição de Santiago del Estero, Córdoba e San Juan, que aproveitavam-se do apoio de Mitre para se afirmarem regionalmente. As longas negociações entre Mitre e Peñaloza atestam o interesse do Estado nacional em obter uma pacificação total, incluindo até os caudilhos mais recalcitrantes. ${ }^{17}$ Apesar destes esforços, a luta só terminou com a morte de Chacho em 1863. Cabe observar que Urquiza, em que pese os muitos apelos feitos por Peñaloza para comandar a resistência contra Buenos Aires, manteve-se neutro, cumprindo o tratado com o presidente Mitre. ${ }^{18}$ Aparentemente, o Estado nacional se afirmava na Confederação Argentina.

\subsection{A guerra e suas repercussões no litoral e no noroeste}

Nos antecedentes da Guerra do Paraguai, os principais alvos da diplomacia paraguaia foram Mitre, de quem se esperava pelo menos neutralidade no caso de uma guerra com o Brasil, e Urquiza, contando com seu apoio militar. A sublevação do colorado Flores contra o governo blanco de Berro - mais tarde Aguirre -, fora recebida com satisfação por parte de Mitre, de quem Flores tinha sido seguidor na guerra contra a Confederação em 1861. Assim, o governo paraguaio entendia a "imparcialidade" do governo argentino em relação à intervenção brasileira no Estado Oriental como um apoio velado aos colorados e ao Império, capaz de comprometer o equilíbrio político no Rio da Prata. Apesar dos apelos dos blancos para uma intervenção, o Paraguai ainda confiava que Mitre não interferisse contra seus interesses, e passou a considerá-lo comprometido após a recusa ao trânsito das tropas paraguaias por Corrien- 
tes para atacar o Brasil. ${ }^{19}$ Numa carta para o ministro argentino Elizalde, José Berges, ministro de Relações Exteriores do Paraguai, escreveu em 29 de março de 1865:

Las ponderadas seguridades de neutralidad que el Gobierno de V. E. manifiesta en una de las notas de 9 de Febrero último, com motivo de su negativa de tránsito al ejército paraguayo para la provincia brasilera de San Pedro de Rio Grande del Sud, no alucinan ya á nadie, y menos al gobierno del abajo firmado, para merecer la consideracion y el crédito que se tributa á las seguridades oficiales de todo gobierno, que respetando la opinion pública, se respete á sí mismo. El Gobierno de V. E. por antecedentes desgraciados, y su política com el Estado Oriental, no estrañará que el del Paraguay no las considere como manifestacion leal de su política hácia esta República. ${ }^{20}$

A desistência de obter algum apoio do governo nacional de Mitre trouxe de volta a necessidade de um acerto com Urquiza, pois "los federalistas y los primitivos caudillos argentinos que aún vivian miraban a Paraguay como al último bastión de la autonomía y la tradición frente al centralismo y la revolución liberal", e uma eventual guerra "daría a los caudillos provinciales, oponiéndose a Buenos Aires y defendiendo los intereses regionalistas, la oportunidad de volver a una Argentina más primitiva". ${ }^{21} \mathrm{Em} 1864 \mathrm{e} 1865$, os enviados paraguaios propuseram a Urquiza açóes conjuntas do Paraguai e Entre Rios, propondo como alternativas para a secessão de Entre Rios e Corrientes, ou mesmo de todas as províncias, exceto Buenos Aires, sob seu comando. ${ }^{22}$ Contando com isso, Solano López

...exagerou na avaliação das contradições internas da Argentina e na possibilidade de que, por exemplo, Entre Rios (ainda sob a liderança de Urquiza) e Corrientes impedissem a Argentina de entrar na guerra contra o Paraguai, ou que, caso houvesse guerra, ficassem do lado paraguaio, e contra Buenos Aires. ${ }^{23}$

Em fevereiro de 1865, López ainda escrevia a Urquiza sobre "las seguridades que espontaneamente $V$. E. quizo ofrecerme sobre la neutralidad del Gobierno Argentino en la luch a entre el Paraguay y Brasil", salientando que "el tránsito de fuerzas paraguayas por alguna parte del território argentino, no importaría un casus belli"; além disso, havia as antigas disputas territoriais que perduravam desde os tempos da independência do Paraguai:

La simple negativa de tránsito por territorio argentino pudiera tal vez tener una explicación, pero cuando esa negativa se estende al territorio nacional [Paraguai] que el Gobierno del General Mitre pretende disputar, no hay explicación honorable que no demuestre la intension de traer el disturbio en las relaciones internacionales de los dos países. ${ }^{24}$

À invasão de Corrientes, Mitre apelou para a fidelidade de Urquiza ao seu governo, fazendo "el debido honor al patriotismo de V. E. y a sus declaraciones, señalandole el puesto que le corresponde en las filas de los leales y valientes argentinos que tienen que vindicar el honor y la dignidad de la República". ${ }^{25}$ Contrariamente ao que esperava López, Urquiza apoiou Mitre repudiando "el ultraje inferido a nuestra patria por el Gobierno del Paraguay", reiterando que "nos toca combatir juntos de nuevo bajo la bandera que nos reunió en Caseros a todos los argentinos". ${ }^{26}$ Com efeito, "Urquiza lanzó grandes proclamas, hizo grandes profesiones de fé, é indujo al pueblo de Buenos Aires a creer, sin vacilacion que marcharia com diez mil hombres, el 26 de Abril, en socorro de los correntinos". ${ }^{27}$ Mas, na carta de 24 de julho de 1865, ele já mostrava as dificuldades de seus propósitos:

Pido al gobierno de mí patria y á V. E., como pido al pueblo de la República algunos dias de espera, para ocupar entonces con el cuerpo de ejército entre-riano que se me ordena levantar, el puesto de peligro que se nos señale, cierto de que no hemos de ser los últimos en concurrir al combate, y que hemos de contribuir, á la par de los mejores, á dejar ileso nuestro honor y el brillo de nuestras armas. ${ }^{28}$

Urquiza mostrava empenho no esforço de guerra, recrutando soldados e fornecendo cavalhadas para o general brasileiro Osório. ${ }^{29}$ Esta foi uma das mais importantes consequências da Guerra do Paraguai para o litoral, pois a adesão de Urquiza aos aliados lhe retirou o papel de principal caudilho fede- 
ral, e sua liderança foi pela primeira vez contestada mesmo em Entre Rios, onde as deserções atingiram proporções alarmantes. A incapacidade de Urquiza em cumprir as promessas feitas mereceu uma observação ferina do vice-presidente Marcos Paz em novembro de 1865:

He tenido el pesar de saber que las fuerzas con que debía concurrir la Provincia de Entre Ríos á la formación del Ejército Nacional, y que el Gobierno de la República habia puesto al mando inmediato de V. E. se han debandado en parte.

(...) habíamos deseado que la Provincia de Entre Ríos tomase parte principal en la lucha (...) pero después del desgraciado suceso de Basualdo, creemos que el contingente de Entre Ríos debia limitarse al menor número compatible con las necesidades del Ejército. ${ }^{30}$

A guerra contra o Paraguai desatava os poucos liames nacionais construídos por Mitre. Mesmo tendo cooptado os favores de Urquiza, este não garantia agora a fidelidade dos montoneros de Entre Rios e Corrientes, que não identificavam como seus os interesses de Buenos Aires, mesmo que travestidos de nacionais. De toda sorte, as sublevações no litoral nunca passaram de deserções ou de atitudes isoladas de reação à convocatória para combater um país que não viam como inimigo; o velho discurso federal contra Buenos Aires ainda tinha mais significados que a ameaça externa.

No norte, no entanto, a situação adquirira mais gravidade, reiniciando as guerras civis. Ainda em 1865, oficiais do governo Mitre noticiavam algumas incursões de antigos seguidores de Peñaloza em La Rioja e manifestavam preocupações de que a mobilização para a Guerra do Paraguai desguarnecesse a província, permitindo o ressurgimento das montoneras no norte argentino. ${ }^{31}$ No ano seguinte, uma sublevação da polícia de Mendoza por problemas salariais permitiu que velhos chefes federales, como Carlos Juan Rodriguez e Juan de Diós Videla, liderassem uma rebelião que se estendeu a San Juan e San Luis, ameaçando La Rioja e Catamarca, conforme noticiou o vice-presidente Marcos Paz para Mitre. ${ }^{32}$ Paz temia ainda as notícias que davam conta de uma volta do coronel Felipe Varela, que tinha sido lugar-tenente de Peñaloza e estava exilado no Chile. ${ }^{33} \mathrm{O}$ fantasma das montoneras reaparecia num momento crítico da Guerra do Paraguai, após a fragorosa derrota dos aliados em Curupaity.

Esses alarmes foram confirmados em janeiro de 1867, quando Varela cruzou a cordilheira à testa de 500 homens, portando uma bandeira com os dizeres “;Federación o Muerte! ; Viva la Unión Americana! ¡Viva el ilustre Cap. Gral. Urquiza! 'Abajo los negreros traidores á la Patria!”. ${ }^{4}$ A alusão aos princípios federales traídos pelo pacto nacional de Mitre, o apelo ao chefe máximo Urquiza, e um discurso "americano" que incluía o Paraguai e rechaçava os "negreiros" escravistas do Império eram muito claros, e conclamavam a uma rebelião generalizada contra o governo nacional. A proclamação de 10 de dezembro de 1866 explicitava estes pontos:

El hermoso pabellón que San Martín, Alvear y Urquiza llevaron altivamente en cien combates (...), ha sido vilmente enlodado por el general Mitre Gobernador de Buenos Aires.

La más bella y perfecta carta constitucional democrática republicana federal (...), ha sido violada y mutilada desde el año sesenta y uno hasta hoy, por Mitre y su círculo de esbirros.

El pabellón de Mayo (...) ha sido coberdemente arrastrado por los fangales de Estero Bellaco, Tuyutí, Curuzú y Curupaity.

(...) ¡Soldados federales! Nuestro programa es la práctica estricta de la constitución jurada, y el orden común, la paz y la amistad con el Paraguay, y la unión con las demás Repúblicas americanas. ${ }^{35}$

Varela em pouco tempo reuniu cinco mil homens, boa parte deles desertores dos recrutamentos para lutar no Paraguai. Derrotado quando tentava tomar a capital provincial de La Rioja, Varela ainda ocuparia Salta antes de exilar-se na Bolívia, de onde ainda faria uma tentativa infrutífera em fins de 1868. Apesar do insucesso em sublevar todo o norte contra o governo Mitre e de não obter qualquer manifestação favorável de Urquiza, essas sublevações federales que pareciam superadas obrigaram ao virtual abandono da Guerra do Paraguai por parte das forças argentinas, tendo Mitre entregue o posto de comandante supremo para Caxias e voltado à presidência do país. Preservar a unidade do Estado nacio- 
nal tornou-se a prioridade do governo argentino, já que o inimigo externo, ao invés de propiciar, dificultara sua concretização.

O envolvimento argentino na Guerra do Paraguai trouxe outras consequências. Em abril de 1870 uma nova insurreição federal abalou Entre Rios, com o assassinato de Urquiza pelo seu lugar-tenente López Jordán. Essa rebelião tinha como motivo inicial o abandono do campo em pleno combate contra Mitre na derrota de 1861, culminando com "el escandaloso aval de la inicua guerra paraguaya", e que "al traicionar Urquiza su deber de caudillo, negándose a cumplir sus compromisos con el pueblo, quedaba reducido a un mero tirano, usufructuario y corruptor". ${ }^{36}$

Quer parecer então que a Guerra do Paraguai não foi facilitadora da afirmação da Confederação Argentina enquanto Estado nacional; ao contrário, integrou o rol de fatores que dificultaram este processo. Tanto no litoral quanto no norte a guerra não apareceu como resultado da agressão de um inimigo externo, comum a todas as províncias, mas como mais uma aventura opressora dos porteños na sua busca de hegemonia, aliados desta vez aos próprios velhos inimigos do Império do Brasil.

\section{Estado Oriental: "algodão entre cristais"}

\subsection{Da Cisplatina ao fim da Guerra Grande}

O final da Guerra da Cisplatina resultou na independência da Banda Oriental como um "Estado-tampão" entre os interesses do Império do Brasil e das Províncias Unidas do Rio da Prata, de acordo com as prescrições inglesas: conforme o representante inglês Lord Possomby, o novo Estado funcionaria como um "algodão entre cristais". Neste sentido, o Tratado Preliminar de Paz - que previa uma ratificação posterior - garantia a independência oriental, mas autorizava o Brasil e a Argentina a "restabelecer" a ordem, conforme o artigo onze:

Ambas as Altas Partes Contractantes declarão muito explicita e cathegoricamente, que qualquer que possa, vier a ser o uso da proteção, que na conformidade do Artigo antecedente se promette, á Provincia de Montevideo, a mesma proteção se limitará, em todo caso, a faser restabelecer a ordem, e cessará imediatamente que esta for restabelecida. ${ }^{37}$

No Estado Oriental, desde o início apareceram disputas políticas, com a imposição de Fructuoso Rivera, um arrivista ${ }^{38}$ que fora brigadeiro do Império na Província Cisplatina, e que desbancara Lavalleja, o comandante que havia liderado a guerra de libertação contra o Brasil. Presidente de 1830 a 1835, Rivera indicara como sucessor a Manuel Oribe, assumindo o cargo de Comandante da Campanha, criando uma dualidade de poder que seria causa de rupturas políticas. Oribe tentou institucionalizar o Estado e combater os caudilhos, o que provocaria a secessão de Rivera, que formaria sua montonera na campanha, contando com a fronteira rio-grandense para sua proteção. Oribe criou o Partido Nacional, que pela cor de suas insígnias, foi chamado de blanco; em contrapartida, Rivera usaria o vermelho, dando origem aos colorados.

Desde então os chefes orientais estariam sempre ligados às disputas entre os caudilhos da Confederação Argentina: ${ }^{39}$ os blancos de Oribe e Lavalleja aos federales de Rosas, os colorados de Rivera aos unitarios proscritos por Rosas, ou aos dissidentes da Confederação, como eventualmente ocorreu com as províncias litoraleñas de Corrientes, Entre Rios e Santa Fé. O Rio Grande do Sul também tinha interesses nestas questões, especialmente durante o decênio farroupilha.

Até 1840 o Paraguai, governado pela mão férrea de Gaspar Rodríguez de Francia, via com muitas reservas as agitações na Banda Oriental. O projeto de Artigas de formação de uma patria grande, que englobasse o Paraguai numa federação, tinha sido rejeitado pelo Supremo. Ao que parece deu apoio financeiro à campanha de Rivera nas Missões Orientais, como retaliação a promessas não cumpridas pelo Império do Brasil quando buscou uma aliança com o Paraguai para a Guerra da Cisplatina. ${ }^{40}$ Em 1842 , o Convênio de Paysandu proposto por Rivera também incluía o Paraguai nesta confederação "mesopotâmica" que fizesse frente ao Brasil e à Argentina, mas Carlos Antonio López não atendeu à convocação, e ainda encaminhou ao Império cópia da ata da reunião que recebera dos signatários. 
As dificuldades para controlar os farroupilhas forçaram o Império a assinar um "tratado de aliança ofensiva e defensiva" com Rosas, em março de 1843, "desejando restabelecer a paz na República Oriental do Uruguay e na Província de Rio Grande de São Pedro", tendo em vista que "os rebeldes da dita província se têm aliado e unido a Fructuoso Rivera, para fazerem a Guerra ao Império e à Confederação Argentina, como provam os documentos autênticos de que ambos os governos estão de posse". ${ }^{41}$ Os primeiros sucessos de Oribe na campanha oriental, no entanto, fizeram com que Rosas recusasse o tratado, temeroso de dividir com o Império uma fácil vitória militar.

No entanto, isso não se cumpriu, e a Guerra Grande se estendeu de 1843 a 1851 na Banda Oriental: os blancos de Oribe somados às tropas de Rosas mantinham Montevidéu sob cerco, e ocupavam a campanha; lá eram fustigados de tempos em tempos pelas guerrilhas de Rivera. O Uruguai tinha agora dois governos que se proclamavam legítimos: o da Defensa, dos colorados na capital sitiada, e o do Cerrito, dos blancos nas cercanias de Montevidéu; ambos pediam o apoio do Império que, se não confiava em Rivera pelo seu passado de identificação com a rebelião farroupilha, temia por outro lado o crescimento da influência de Rosas na Banda Oriental.

Pacificado o Rio Grande do Sul, abria-se para o Império a possibilidade de intervenção no Prata, desde que obtivesse alguns apoios, e daí o interesse em uma aproximação com Carlos Antonio López; foi firmado, assim, um tratado, onde se destacava o compromisso dos signatários na preservação da independência uruguaia: ${ }^{42}$ para o Brasil, era mister que o Estado Oriental não voltasse à condição de província argentina, o que ampliaria a força de Rosas, o que também para o Paraguai seria nefasto devido às intenções da Confederação em reincorporar este país como mais uma província.

Um ano depois, em 1851, a rebelião de Urquiza contra Rosas permitiu a aliança do Império com as províncias do litoral e com os colorados, derrotando as tropas de Oribe primeiro, e derrubando o governador de Buenos Aires em 1852. Isso afiançava para o Brasil a navegação dos rios interiores e o acesso ao Mato Grosso. Além disso, o extenso tratado com o novo governo oriental em outubro de $1851^{43}$ transformava o Uruguai numa área de forte influência do Império, com tantas vantagens territoriais, pecuniárias e fiscais, que o acordo foi considerado uma virtual "recisplatinização".

Assim, depois da queda de Rosas em 1852, os destinos de Paraguai e Uruguai exerceram papéis similares, atuando como pequenos Estados inseridos entre os projetos hegemônicos da Confederação e do Império. Mas foi a partir do cisma entre os federales de Urquiza e os unitários de Mitre - quando Buenos Aires procurou manter-se independente da Confederação - que os interesses políticos no Estado Oriental passaram a pesar muito em relação aos destinos do Paraguai, e aqui foram fundamentais algumas mudanças nas alianças entre os diferentes atores políticos do espaço platino.

Os blancos orientais, outrora aliados fiéis aos federales de Rosas, restabeleciam suas relações com o vencedor Urquiza, que tentava recompor a Confederação retirando o papel central de Buenos Aires. Já os colorados mantinham seus antigos vínculos com os unitários que agora retornavam às arenas políticas portenhas. Os rio-grandenses, que detinham muitas estâncias e gados em terras orientais ao norte do Rio Negro, indispunham-se com os blancos da região, que se ressentiam dessa competição; já os colorados, em sua maioria produtores mais modernizados ligados ao porto de Montevidéu ou ao comércio, tinham boas relações com as gentes do Rio Grande. Assim, as alianças preferenciais se faziam entre unitários de Buenos Aires, colorados e rio-grandenses, tendo no outro campo federales do litoral e blancos. O Império, nessa situação, teria dificuldades em manter uma "neutralidade expectante" em face dos assuntos do Rio da Prata, e a presença brasileira neste cenário passaria a preocupar o Paraguai.

\subsection{A grave crise dos anos sessenta}

As desavenças entre blancos e colorados antes da Guerra do Paraguai tiveram a participação rio-grandense, especialmente aqueles que tinham terras na Banda Oriental. O tratado de 1851 lhes dera muitas prerrogativas, como facilidades para transitar reses para as charqueadas do Rio Grande, impostos que 
encareciam o charque uruguaio e a extradição de escravos fugidos que podia ser solicitada pelo presidente da província, sem a necessidade de consulta às autoridades centrais. Este tratado viabilizara a volta dos colorados ao poder, e eram eles os fiadores das cláusulas acordadas; assim, sempre que os blancos voltavam a ocupar a presidência, eram discutidas as pautas favoráveis aos rio-grandenses, que reagiam fortemente na defesa de seus interesses privados.

No início dos anos 1860, seria marcante a condução do general Antônio de Souza Netto, o chefe farrapo que proclamara a República Rio-Grandense e que vivia em terras uruguaias desde 1845 . Netto já enfrentara problemas com os blancos de Oribe durante a Guerra Grande, e agora se indispunha contra o presidente blanco Berro, por interferências do Estado nos assuntos privados dos estancieiros riograndenses, como o trânsito do gado pela fronteira e a questão dos escravos. Assim, quando iniciou a rebelião de Venancio Flores em abril de 1863, Netto o apoiou, criando uma situação muito séria para o Império, que terminaria se envolvendo no conflito da Banda Oriental.

Também as alianças das diferentes facções orientais e argentinas influíram na ação do presidente Mitre em relação às disputas uruguaias. Além da já histórica aproximação entre colorados e unitários, Flores fora das forças de Mitre quando do enfrentamento contra Urquiza, e era general da Confederação. A presença de Flores na presidência uruguaia reforçava a posição de Mitre, que enfrentava ainda a montonera de Peñaloza e não podia descartar totalmente um novo levante de Urquiza, que poderia contar com os blancos como aliados. Assim, "tanto a Argentina como o Brasil apoiaram os colorados na sua luta contra os blancos, e Mitre não acreditou que os interesses argentinos, inclusive a contínua independência do Uruguai, estivessem ameaçados pelo que ele esperava ser uma breve intervenção cirúrgica do Brasil no Uruguai, em defesa de seus próprios interesses". ${ }^{44}$

Não havia ainda um apoio explícito de Mitre a Flores, e o ministro argentino Elizalde propalava a neutralidade da Confederação. Já os rio-grandenses pressionavam o Império afirmando que "se a nacionalidade não serve a nossos compatriotas para serem respeitados no exterior, não lhes servirá para nada mais", ${ }^{45}$ trazendo à tona o fantasma da secessão farroupilha; cada vez mais os assuntos das regiōes-províncias se impunham, e os Estados nacionais em construção tinham enormes dificuldades em resolvê-los. Para o Brasil, o envolvimento na questão oriental tornava-se mais satisfatório do que uma ruptura com os "senhores guerreiros" do Rio Grande, fundamentais para qualquer política impositiva do Império no Rio da Prata.

O Paraguai observava a questão oriental com muitos cuidados. Assim, no início de 1864, "el gobierno paraguayo envió al argentino una nota, quejándose del auxilio y proteccion moral dada por este al rebelde Flores". ${ }^{46}$ A situação tornou-se crítica a partir do ultimatum formulado em 4 de agosto do mesmo ano pelo representante brasileiro José Antônio Saraiva, dando um prazo de seis dias para que o governo blanco de Aguirre indenizasse os prejuízos alegados pelos rio-grandenses. A julgar pelas negociações que em julho tivera com Elizalde em Buenos Aires, pode-se concluir que o governo Mitre estava a par da projetada intervenção militar do Império contra o governo de Aguirre, ${ }^{47}$ e que a paz no Estado Oriental só seria alcançada com a subida dos colorados ao poder.

Por sua vez os blancos, sem o apoio que esperavam dos federales de Urquiza, recorreram ao outro Paraguai como aliado contra os expansionismos da Confederação e do Império, a República do Paraguai: "Cuando llegaron á la Asuncion las noticias del ultimatum brasilero, el ministro oriental propuso al gobierno del Paraguay interviniera en el Rio de la Plata com su escuadra y ejército." O ministro José Berges, apesar da solidariedade com o governo oriental, ainda agia com cautela em relação à crise:

La nota paraguaya (...) revela todas las iconfidencias diplomáticas del ministro oriental. Entre otras cosas declara, que el ministro oriental en su capacidad oficial, le habia propuesto una alianza ofensiva y defensiva contra el gobierno argentino, que el mismo ministro habia declarado que la isla de Martin Garcia pertenecia de derecho á la Banda Oriental, ofreciendo mantenerla neutral dado el caso que su gobierno se apoderara de ella; que el ministro habia propuesto irse á Montevideo y desde alli, enviar un emisario para ligar una intriga com Urquiza, gefe de la provincia de entre Rios y tratar de decidirlo á declararse contra el gobierno de la República Argentina, pronunciándose en favor de Montevideo. 
El ministro Berges concluye su despacho diciendo, que su gobierno no cree conveniente intervenir com escuadra y ejército en el Rio de la Plata como lo proponia el gobierno oriental; pero que siendo esencialmente necesario al bienestar del Paraguay, el equilibrio del Rio de la Plata, su gobierno se reservaba al derecho de asegurar este resultado por su accion independiente y propia. ${ }^{48}$

O Paraguai ainda não se comprometia militarmente, mas seu ministro Berges protestou com veemência contra a intervenção brasileira nos assuntos uruguaios, conforme nota a Vianna Lima, representante brasileiro em Asunción, em 30 de agosto:

El gobierno de la República del Paraguay deplora profundamente que el de S. E. haya creido oportuno separarse en esta ocasion de la política de moderacion en que debia confiar ahora mas que nunca, despues de su adhesion á las estipulaciones del Congreso de Paris, pero no puede mirar com indiferencia ni menos consentir que en ejecucion de la alternativa del Ultimatum imperial, las fuerzas brasileras ya sean navales o terrestres, ocupen parte del territorio de la República Oriental del Uruguay ni temporaria ni permanentemente, y S. E., el Sr. Presidente de la República ha ordenado el abajo firmado declare á V. E., como representante de S. M. el Emperador del Brasil: que el Gobierno de la República del Paraguay considerará cualquiera ocupacion del territorio oriental por fuerzas imperiales por los motivos consignados en el ultimatum de 4 de este mês, intimado el gobierno oriental por el ministro plenipotenciario del emperador, en mision especial cerca de aquel gobierno, como atentatorio al equilibrio de los Estados del Plata, que interesa a la República del Paraguay como garantia de su seguridad, paz y prosperidad, y que protesta de la manera mas solemne contra tal acto, descargándose desde luego de toda la responsabilidad de las ulterioridades de la presente declaracion. ${ }^{49}$

A posição paraguaia era clara em relação à intromissão brasileira na Banda Oriental, e apelava para um "equilíbrio" no Prata que, se desfeito, comprometeria a própria independência do Paraguai. As ameaças de interferência no conflito não se fundamentavam somente no seu poderio bélico, mas contando com as dissidências dos antigos federales, que teriam uma oportunidade de revanche. Mas as negociaçôes com Urquiza não o animaram a posicionar-se a favor dos blancos e contra Buenos Aires. Por outro lado, a Confederação e o Império reclamavam suas prerrogativas de intervirem sempre que houvesse distúrbios no Uruguai, porque "a paz da República Oriental do Uruguai é a condição indispensável para a solução completa e satisfatória de suas questôes e dificuldades internacionais com a mesma República".$^{50}$ Esta posição de tutelares da independência oriental foi explicitada por Rio Branco, representante do Império, para o colega argentino Elizalde em janeiro de 1865:

En estas disposiciones confiaba el gobierno imperial, cuando le sobrevino el conflicto con el de Montevideo, y se vió com espanto en el Rio de la Plata presentarse el gobierno de la Asuncion como el mas celoso defensor de la independencia de la República Oriental del Uruguay, que nadie sériamente podia juzgar amenazada por el Brasil, por el Brasil que la defendiera contra el poder de Rosas y sin el concurso á que el gobierno paraguayo se obligára en el citado pacto de 25 de Deciembre de $1850 .^{51}$

O conflito com o Império aproximava-se e aos paraguaios restava neutralizar os argentinos, pois era essencial a permissão do presidente Mitre para o trânsito do exército paraguaio através de Corrientes para atacar o Brasil. Assim, a recusa deste pedido representou para o Paraguai uma ruptura das relaçôes com a Argentina, como declarou o ministro José Berges em carta para Elizalde de 29 de março de 1865:

Las ponderadas seguridades de neutralidad que el Gobierno de V. E. manifiesta en una de las notas de 9 de Febrero último, com motivo de su negativa de tránsito al ejército paraguayo para la provincia brasilera de San Pedro de Rio Grande del Sud, no alucinan ya á nadie, y menos al gobierno del abajo firmado, para merecer la consideracion y el crédito que se tributa á las seguridades oficiales de todo gobierno, que respetando la opinion pública, se respete á sí mismo. El Gobierno de V. E. por antecedentes desgraciados, y su política com el Estado Oriental, no estrañará que el del Paraguay no las considere como manifestacion leal de su política hácia esta República.

Nadie ignora que un general argentino [Flores], se introdujo en la República Oriental sin causa ni motivo, ni aun llamado por el partido político á quien decia pertenecer para revolucionar el país y combatir el go- 
bierno legal y la poblacion oriental com elementos brasileros y porteños, reclutados y suministrados por un comité revolucionario oriental que funcionaba com escándalo públicamente en la hoy capital de la Confederacion Argentina, bajo la vista y connivencia del Gobierno Nacional... ${ }^{52}$

O Paraguai promovia a guerra contra as duas maiores potências sul-americanas pensando ainda numa adesão das províncias do litoral, mas "los disidentes argentinos se encontraban sin líderes porque Urquiza se comprometió en la guerra y se convertió en uno de los principales proveedores del ejército argentino". ${ }^{3}$ Conforme Thompson, López contava ainda com Urquiza e poderia ter conduzido a guerra visando comprometer mais diretamente o supremo entrerriano:

Si hubiera marchado hasta Entre-Rios, es muy posible que Urquiza se hubiera plegado á él. En presencia del aspecto que tomaban los acontecimientos, los aliados concebieron una pobre idea del poder de Lopez, á consecuencia del fácil y completo éxito de las primeras operaciones de la campaña. (...) Es mas probable que tenia la esperanza de que Urquiza ayudara a Estigarribia, pero no habia tratado al efecto, aunque no hay duda que Urquiza indujo á Lopez á esperar su apoyo, pues sus ajentes iban y venian constantemente. Se animaba sin cesar al ejército paraguayo, haciéndole creer que Urquiza estaba á punto de plegarse á sus banderas. Se decia tambien que Bolivia haria una alianza com el Paraguay y que 12000 bolivianos marchaban á Matto-Grosso. La prensa chilena era el único apoyo estranjero com que Lopez contaba en esta época. ${ }^{54}$

A Guerra do Paraguai envolveu o Uruguai e seu presidente provisório, Flores, assumiu o comando dos efetivos orientais. Com alguma atuação na retomada de Uruguaiana, os uruguaios tiveram um papel secundário no conflito que, depois de 1867, seria praticamente uma guerra apenas do Império do Brasil. As disputas entre blancos e colorados não seriam apagadas pelo inimigo externo, e ainda recrudesceriam: Flores, que se mantinha apoiado pela Confederação e pelo Império, foi assassinado pelos blancos que, no mesmo dia, sofreram o homicídio de seu líder Berro:

El gobierno de los años de guerra de Venancio Flores no fue estable; era una dictadura que terminó con la fusión y dio a los colorados el monopolio del poder, provocando la inevitable oposición de los blancos y de otros grupos. Uruguay se dividió en bandos contendientes y Flores y Berro fueron asesinados el mismo día, el 19 de febrero de 1868. Cuando se desintegró el gobierno y Uruguay se deslizó irremediavelmente hacia el desorden y el caudillismo, la economía y la sociedad disfrutaron de gran autonomía y se produjeron grandes transformaciones. Pero, si bien la anarquía política no evitó automáticamente el crecimiento económico, el cambio económico tampoco restableció inmediatamente el equilíbrio político. ${ }^{55}$

A militarização do Uruguai ao longo dos anos 1870 postergaria as disputas entre os dois partidos para o final do século XIX e início do XX: as montoneras do chefe blanco Aparicio Saravia de 1904 atestavam a sobrevivência de antagonismos ainda não controlados pela organização nacional do presidente colorado Batlle y Ordoñez. Assim, também neste país, a Guerra do Paraguai não servira para criar uma identidade nacional que superasse os antagonismos existentes no seio das oligarquias orientais; ao contrário, accirrara estas disputas e dificultara ainda mais a institucionalização política.

\section{Rio Grande de São Pedro: entre o Império e o Prata}

\subsection{O Rio Grande em face do Prata}

Os rio-grandenses tinham um histórico de conflitos e convivências com os platinos que lhes permitiu, ao longo do século XIX, uma série de ações políticas que não diziam respeito aos interesses maiores do Império. Assim foi na Cisplatina, quando a ocupação de terras e o sequestro de gado impediram que Lecor, presidente da nova província, obtivesse a desejada paz para efetivar a incorporação da Banda Oriental.

Durante a secessão farroupilha, os rio-grandenses buscaram apoios de Rosas e Oribe primeiro, na condição de "federales" contra "unitários" da Corte. ${ }^{56}$ Já a partir de 1838 até o final de 1842 , as alianças mudaram para os colorados de Rivera, com quem firmaram dois tratados, ${ }^{57}$ federales dissidentes, com 
os quais fizeram o Tratado de Corrientes e o Convênio de Paysandu. Além disso, Garibaldi, corsário e chefe militar da República Rio-Grandense, organizou em 1843 a "marinha" de Rivera para combater a esquadra de Rosas, motivando o fechamento da legação imperial em Montevidéu. ${ }^{58}$ Com o Paraguai foram feitas algumas aproximações, que foram rechaçadas por Francia e Carlos Antonio, ${ }^{59}$ receosos de comprometimentos contra o Império do Brasil.

Após a paz com o Império, os rio-grandenses se envolveram em conflitos com os blancos de Oribe que ocupavam a campanha oriental e mantinham Montevideo sob cerco. Nestas disputas, destacaram-se Souza Netto, general farroupilha que emigrara para o Uruguai, e Francisco Pedro de Abreu, general legalista durante a Guerra dos Farrapos. Netto, agora estancieiro em terras orientais, alegava tropelias dos blancos, e chefiava guerrilhas contra Oribe; ${ }^{60}$ também reclamava de Caxias - na presidência do Rio Grande - pedindo proteção para os súditos do Império na Banda Oriental.

Já Francisco Pedro promovia ataques rápidos a partir da fronteira, saqueando gados e libertos que serviam com os blancos. O Império acatou as queixas formais de Oribe e Rosas, condenando estas expediçóes, conhecidas como "califórnias"; Chico Pedro, no entanto, tinha apoio dos estancieiros e comandantes fronteiriços, e continuou agindo com total liberdade, como mostra a mensagem de 26 de dezembro de 1849 :

Brasileiros! É tempo de correr às armas e despertar do letargo em que jazeis. Uma série de fatos horrorosos, que têm cometido esses selvagens invasores no Estado limítrofe para com nossos patrícios, e propriedades, não vos são ocultos; e reconhecendo vosso valor, e patriotismo, o chefe que firma vos convida a reunir-vos ao ponto marcado, e desta arte salvarmos a Honra Nacional, e as nossas propriedades extorquidas, e creio que não sereis indiferentes a esse sagrado dever. ${ }^{61}$

A intervenção imperial na questão oriental necessitava dos chefes do Rio Grande, para os quais agora a honra nacional se associava com extorsões e invasóes de propriedades. Pouco tempo depois de formalizada a intenção do Brasil em intervir no Prata, Domingos José de Almeida, antigo ministro farroupilha, escrevia:

S. Exa. o Sr. Conde de Caxias, Presidente da Província e Comandante em chefe do Exército, me incumbiu da honrosa comissão de convidar aos meus companheiros de trabalhos para coadjuvá-lo no afanoso empenho em que se acha de vingar os ultrajes que nossos compatriotas estabelecidos no Estado Oriental têm recebido das autoridades dele, de reclamar pronta indenização dos bens que lhes hão extorquido e de prefixar definitivamente os limites do Império com o referido estado... ${ }^{62}$

$\mathrm{Na}$ guerra do Império contra Oribe em 1851 e Rosas em 1852, em aliança com os colorados e as tropas de Urquiza, os rio-grandenses constituíam um terço do exército brasileiro, formando quase toda a cavalaria. ${ }^{63}$ Foram eles os grandes beneficiários do tratado obtido com o Uruguai, tanto na definição dos limites quanto em vantagens para a pecuária e para as charqueadas sulinas. Além disso, no triunvirato provisório nomeado para o Uruguai, estavam Lavalleja e Rivera, velhos conhecidos dos homens da fronteira, e Venancio Flores, com quem se iniciava uma parceria que teria repercussóes na conjuntura que antecederam a Guerra do Paraguai.

\subsection{O Rio Grande na Guerra do Paraguai}

No início dos anos 1860, as reclamações dos rio-grandenses em relação aos blancos recrudesceram; temendo pelos seus interesses no Uruguai, ignoravam as autoridades centrais, agindo por conta própria. Em fins de 1863, a Corte via com muita preocupação estas ações privadas junto do colorado Venancio Flores contra o governo blanco, como escrevia o Marquês de Abrantes ao presidente da província:

O governo imperial viu com amargura que apesar de suas insistentes e reiteradas ordens e recomendações, a causa da rebelião que vem atingindo o Estado Oriental continua encontrando o apoio e a participação de alguns brasileiros irreflexíveis, que desconhecendo seus próprios deveres e os de seu país expõem o governo a acusações de deslealdade em suas declaraçôes solenes e talvez a conflitos internacionais de conseqüências gravíssimas. ${ }^{64}$ 
Novamente o general Antônio de Souza Netto era o principal protagonista, fazendo-se porta-voz dos brasileiros residentes na Banda Oriental. Os problemas privados sobrepunham-se aos nacionais, e a audiência de Netto na Corte em março de 1864 criara um impasse para o Império, que preferia atender aos seus reclamos do que arcar com outra guerra civil, como escreveu o agente Mármol ao presidente Mitre:

Os interesses de um caudilho rio-grandense colocaram em março de 1864 o governo imperial diante da alternativa de sufocar com armas algum desacato à autoridade soberana no Rio Grande, ou de fuzilar orientais, satisfazendo o general Netto em suas pretensões de auxiliar o revolucionário Flores. A coisa não lhe pareceu grave, e o Brasil escolheu fuzilar os orientais. ${ }^{65}$

Também pensava assim o ministro do Brasil na Inglaterra, Carvalho Moreira, afirmando que "o Imperador do Brasil foi obrigado pelo general Netto do Rio Grande a intervir (...) sob pena de que esse general e a Província do Rio Grande se levantassem e fossem totalmente perdidos para o Império" ${ }^{66}$ As dificuldades para a organização nacional mais uma vez fizeram a Corte intervir no Uruguai, favorecendo os rio-grandenses, e este foi o estopim para a ruptura do Paraguai com o Império.

Os homens da fronteira participaram do esforço de guerra como na campanha de 1851-1852, mas sem as vantagens daquela ocasião: ao invés de benefícios territoriais e econômicos, os "senhores da guerra" tiveram que enfrentar os inimigos em seu próprio território e os mandos indesejados de comandantes imperiais. São exemplares os desagrados de dois antigos chefes farroupilhas, Canabarro e Lucas de Oliveira.

David Canabarro fora o último comandante farroupilha e o signatário do acordo de paz com Império. Veterano combatente nas guerras sulinas desde a Cisplatina, granjeara fama como um chefe atilado de milícias. Já nos estertores da secessão rio-grandense, escapava sempre do poderoso assédio que lhe movia Caxias. Reincorporado às forças armadas do Império, tinha participado da campanha de 1851-1852 e, nos anos sessenta, encontrava-se como responsável pela fronteira das Missões e do Quaraí.

Nas vésperas da guerra estava muito atento à possibilidade de Venancio Flores combater o governo blanco e as repercussões que isso podia trazer para Urquiza para o Paraguai. Assim escreveu Canabarro para o presidente da província José Marcelino Gonzaga em 30 de setembro de 1864:

Como V. Mcê. nada sei de positivo quanto à opinião de Urquiza emitida a Flores quanto a ser este ou não general brasileiro. Estamos (isto é, o Governo), de acordo sobre os negócios orientais com Mitre; seria estranho que Urquiza, apenas General Comandante de Armas de Entre Rios e subordinado a Mitre, viesse contra aliados de Mitre.

O certo é que em troca de notas entre o nosso Ministro e de Paraguai, na Assunção, a 30 de agosto, e 1, 2, e 3 do que finda, o Paraguai declara que seu Governo jamais consentirá que o do Brasil invada por forças navais ou terrestres, temporária ou permanentemente, o Estado Oriental, porque seria abalar o equilíbrio das repúblicas do Prata. Que sentia ter de empregar força contra força. ${ }^{67}$

Iniciada a guerra, Canabarro voltou-se para o exame das possibilidades de invasão do Brasil, e a eventual aliança de López com Urquiza. Assim, o exército imperial devia preparar-se para resistir, como escreveu em 29 de dezembro de 1864: “... teremos 3800 homens organizados, além da reserva. Esta força numérica resfria o ardor de 8000 paraguaios na tentativa de transpor o Uruguai, pois eles sabem que o Exército Brasileiro não está no fim do mundo.”

A conspiração de Urquiza em Entre Rios e Corrientes tem de haver-se primeiro com a força do Governo da Confederação; se unido aos paraguaios tanto maior será o empenho da Confederação em suplantá-lo; é um inimigo que a Confederação, por sua segurança, não deve consentir em vê-lo forte. (...) Esta guerra do Paraguai abriu uma situação nova, que reclama a criação de Exército Brasileiro em pé de 30.000 homens, para ocupar a posição que lhe cabe entre as nações vizinhas. Pôr o Flores na Presidência e seguir ao Paraguai... ${ }^{68}$

Para conter os paraguaios o Império, além de um governo confiável no Uruguai, precisava guarnecer-se mais na fronteira. A preocupação com a fidelidade de Urquiza ao presidente Mitre ainda era manifesta na correspondência que enviou para Gonzaga, em 1ํo de janeiro de 1865 : 
Hoje oficialmente digo a V. Exa. que convém não perder de vista as Províncias de Corrientes e Entre Rios, porque a aliança deles com o Paraguai nos faria estremecer na ausência de nosso Exército.

Esperemos as manifestações do presidente Mitre demonstradas pela existência de força que naquelas Províncias imponha silêncio às ideias que germinam em favor do Paraguai. Urquiza é um caudilho audaz, que pode levantar cavalos e, unido a Paraguai, se torna perigoso a Mitre e a nós. É assim que tanto o Paraguai como Urquiza nos impelem àquele aliado de alta conveniência.

Se Paraguai contasse decididamente com Corrientes e Entre Rios e ao menos com a neutralidade de Mitre parece que não perderia a ocasião de vir socorrer aos seus protegidos no Oriental, os Blancos; mas ele encaminha-se para Mato Grosso e aí os deixa a braços. ${ }^{69}$

No dia 27 do mesmo mês, Canabarro ainda ponderava ao presidente sobre os cuidados com Urquiza, salientado que "por agora temos o Paraguai declarado e duvidosa a conduta de Corrientes e Entre Rios onde está esse famoso caudilho Urquiza, com visos de neutralidade, enquanto seus satélites cruzam-se em missóes secretas ao Paraguai e Blancos, e rumorejam contra nós". ${ }^{70}$ Sobre a fronteira, ele respondeu em 13 de fevereiro um ofício de Rio Branco, acerca do pedido de trânsito que o Paraguai encaminhara a Mitre, e das forças armadas de que dispunha para a invasão:

Elles podem auxiliar a seus alliados, ou indo a Montevidéo, ou invadindo estas fronteiras.

Passar ao Estado Oriental, em direcção a Montevidéo, com o número de 9 ou mesmo 12.000, seria antecipadamente capitular e entregar as armas.

Invadir a nossa fronteira do Uruguay é menos perigoso, mas não estão isentos da derrota infallivel si esta divisão fôr reforçada convenientemente e a tempo. Actualmente tem ella mui proximamente 4.000 homens (...)

Nenhuma divisão de operações se diz convenientemente organizada, sem as tres armas. Esta tem somente cavallaria, carece de infantaria de linha e de artilharia. Ha na provincia desses batalhōes e artilharia, que deviam fazer parte da defesa do Uruguay. Si houvesse aqui 2.000 homens de infantaria e artilharia e armamentos para 6.000 de cavallaria, affirmo a V. S. que 12.000 paraguayos poucos dias haviam de contar desde a passagem à margem esquerda do Uruguay ao da sua completa derrota.

(...) depende só de determinação do Governo.

(...) Eu espero que V. Ex. faça sentir a necessidade de collocar esta divisão no pé de guerra conveniente. ${ }^{71}$

Mas o Império não tomou as medidas solicitadas. Assim, as tropas paraguaias de Estigarríbia invadiram Corrientes, cruzaram o rio Uruguai e tomaram São Borja, enquanto Canabarro recuava sem dar combate. A incursão paraguaia prosseguiu até a ocupação de Uruguaiana, enquanto um pequeno contingente seguia pela margem correntina até a localidade de Libres. Pela decisão de não enfrentar os invasores foi submetido à corte marcial; em sua defesa, Canabarro criticou as omissões dos homens da Corte em relação aos seus rogos, como no arrazoado de 3 de outubro de 1865:

Se tivéssemos de 5 a 6 mil homens de Infantaria não havia mais do que marchar e bater o inimigo da Província. Porém com dois mil infantes, 8 bocas de fogo e Cavalaria, por única operação tínhamos que marchar em retirada na frente do inimigo (...)

Comparemos: a Infantaria paraguaia montava a mais de 7000 porque tudo se tornava Infantaria. (...) Para mim as massas de Infantaria são uma fortaleza movediça, uma rocha viva, em que a Cavalaria vem qual a onda espumante quebrar-se e recuar. O Exército que um General comanda é a arma com que vai jogar na luta com seus adversários, deve pois conhecê-las para entrar na lide. Tínhamos Cavalaria sem instrução, indisciplinada, armada em parte e montada em maus cavalos. Infantaria $2^{\circ}$ e 10 de Linha, comandantes e oficiais que davam exercício a seus soldados e que os sabiam conduzir a combate; o $1^{\circ}$ e $5^{\circ}$ de Voluntários apenas organizados no Rio de Janeiro embarcaram, nesta Província sempre em marchas nada podem saber e mesmo de seus oficiais só aqueles já conhecedores da arma. Artilharia no exercício a fogo que presenciei no Ibirocaí o alvo ficou sem ofensa alguma, antes perto de mim passou uma bala, que se afastara dele quase uma quadra. (...) O inimigo tinha 6 Batalhōes a 800 praças cada um, atendendo a desfalques, e 4 Regimentos de Cavalaria a 600 cada um, Cavalaria que também era Infantaria quando preciso, cinco bocas de fogo e 32 carretas.

(...) Todavia acrescentarei que V.Ex ${ }^{a}$ mandou examinar pelo capitão Fernandes Sampaio o estado daquela fortificação [Uruguaiana] e quantos homens precisos para a sua defesa. A resposta foi de 4 mil infantes; ape- 
nas havia dois mil e os clavineiros. (...) Suponho que V. Exa não ordenou a defesa da vila pela má fortificação e pessoal exigido, enquanto o que havia à disposição ficaria a risco de ser batido ali encerrado, tanto mais que se não podia precisar a chegada do General Flores [Venancio]. Na noite de 4 de agosto a 2a Brigada ao mando do coronel João Antônio da Silveira foi levantar o armamento se porventura ainda não estivesse embarcado, porém visto que já nenhum havia procurou salvar os gêneros do fornecimento de víveres; busca o depósito, a casa fechada. (...) Às 9 da noite de 5 de agosto chegava o tenente-coronel Pereira e declarou da parte do general Flores que visto a proximidade do inimigo ele não podia chegar a tempo de obstar a entrada na Uruguaiana, e que estando perto o general Paunero [do exército de Mitre], que procura junção com ele, tinha a pôr em prática a mais importante operação que vinha a ser bater primeiro a força paraguaia da margem direita, porque batida essa restava a operação sobre a da Uruguaiana (...) Projetar é fácil, executar dificílimo. ${ }^{72}$

As cobranças feitas a Canabarro lhe pareciam injustificadas porque ele havia feito o que era possível contando apenas com a Guarda Nacional que organizara; o Império fracassara no fornecimento de infantes e artilheiros competentes, não providenciara oficiais experientes, falhara no abastecimento de víveres, armas e munições. Mais que isso, desconhecia ainda as características da cavalaria ligeira, a arma por excelência dos rio-grandenses, eficiente nas ofensivas e na guerra de movimento, mas limitada para manter posições. As recriminações mútuas se assemelhavam àquelas trocadas depois da batalha do Passo do Rosário que, em 1828, decretara a perda da província Cisplatina. A convicção de Canabarro era tanta, que no mesmo 3 de outubro apontava:

A Província estaria defendida da invasão de 10 de junho, se nas fronteiras tivesse ao menos 5 mil homens de Infantaria com a cavalaria organizada, até podia tomar a ofensiva contra esses mesmos invasores que vieram de São Carlos. O Ministério da Guerra não preveniu como convinha a fronteira do Uruguai contra a invasão há muito prevista e esperada, e é do Ministério da Guerra que partem as recriminações por falta de tiros nos passos contra aqueles que a despeito de faltas fizeram o que estava ao seu alcance e entregaram o inimigo ao poder dos aliados. ${ }^{73}$

Depois disto, Canabarro retirou-se da linha de frente e foi tratar dos seus negócios privados na estância de Santana do Livramento, onde morreria em 1867.

Manuel Lucas de Oliveira, também um dos líderes da República Rio-Grandense, após a paz de 1845 tornou-se coronel da Guarda Nacional, e participou das guerras de 1851 e 1852. Em 1864, iniciou o seu diário quando começou a organizar voluntários para a iminente invasão dos paraguaios. Era chefe militar da fronteira com o Uruguai, e se preocupava com as tropelias dos blancos contra os rio-grandenses pelo apoio que haviam dado a Venancio Flores, como escreveu para Caxias em 17 de março de 1865:

Em dias de setembro último, escrevi a V. Exa. de Porto Alegre, por que previa que no estado de desorganização e desordem em que começavam a marchar as coisas, não nos era possível atravessar a crise sem termos que lamentar algum infortúnio, e este por nossa desgraça, verificou-se em Jaguarão, com a invasão dos bárbaros blanquilhos, que assassinaram, roubaram, violaram famílias, cometeram toda a classe de atrocidades, roubando-nos mais de 3 mil cavalos, que bem falta nos devem fazer; além de ser uma mancha negra que lançou no Pavilhão Nacional, a incúria ou a imbecilidade dos homens que dirigiam o movimento das tropas para o Estado Oriental, sem deixarem bem guarnecidas nossas fronteiras, ou por melhor, sem nenhuma guarnição. ${ }^{74}$

O apelo a Caxias visa alertar um chefe militar que mostrou competência, como guerreiro e como político, e que poderia exercer influência junto à Corte para atender às demandas dos rio-grandenses. Lucas de Oliveira também aproveita a intimidade do diário para destilar suas opiniōes mordazes contra o Império, duvidando mesmo de sua lealdade para com a província, como observa em 25 de março:

...o governo do Brasil sempre foi e é branquilho e que se não fosse o aprisionamento do marquês de Olinda no Paraguai, o nosso Exército, em vez de atacar Paissandu, haveria voltado suas armas contra o general Flores e o Neto!!! Fundando-se em argumentos que não podem destruir-se, como as prestaçóes pecuniárias de Matias, seus acordos com Aguirre, Urquiza e seus infames partidários, etc., (...) os atos de Gonzaga e seus asseclas, não querendo utilizar os serviços de chefes que ele tinha a certeza de não se ligarem ao par- 
tido blanco, ou os que consideravam os maiores algozes dos rio-grandenses, cujo modo de pensar é um crime para o senhor Gonzaga e os ministros que para cá o remeteram de encomenda!!!

(...) Pois o Povo já fala sem rebuço e quer sustentar com provas que o governo nos atraiçoa e que isto que até aqui tem sucedido, não são desacertos - é a mais agravante traição para pisar aos pés o Rio Grande... Deus queira que assim não seja. ${ }^{75}$

Lucas rememorava antigas alianças do Império com blancos de Oribe para combater os farrapos e os colorados. A afirmação de que a Corte só agira após o ataque do Paraguai e a crítica ao presidente provincial - o mesmo a quem Canabarro se dirigira sem obter respostas - eram acusações de ações dolosas da Corte contra os rio-grandenses, não apenas descaso. A entrada da Argentina na guerra desperta em Lucas dúvidas quanto à conduta de Urquiza, como escreveu em 23 de abril:

Confirma-se a notícia da guerra do Paraguai com os Portenhos: aí temos, portanto, decidido Urquiza contra os Portenhos e por consequência contra o Império. É em que tinham de vir a dar as demoras, os desacertos e as debandadas de nossa organização militar!!! Apertem agora o gorro, senhores Mariolas!!! ${ }^{6}$

Em 28 de abril, comenta que Canabarro oficiara ao presidente da província dando conta que "os Paraguaios reforçaram seu Exército com 5 mil correntinos - Federais - e não tardará que o reforcem com Urquiza e seus partidários, etc." ${ }^{77}$ A despeito de tudo, o Império não tomara as medidas contra a invasão. Por outra parte, Lucas duvidava da capacidade militar de Mitre, como aponta em 9 de maio:

Vi os Jornais do Echo até 7, e neles (...) o grito de alarme de Mitre aos Portenhos, dizendo-lhes: - convoquemse os Cidadãos todos para correr, em 24 horas, ao Quartel, em 15 dias à campanha, em 6 meses à Assunção. Gosto desta balandronada castelhana!!! Veremos se assim sucede. ${ }^{78}$

Manuel Lucas de Oliveira fazia uma previsão acurada da situação política na Confederação, e muito brevemente Mitre ver-se-ia às voltas com deserções e fracassos militares no Paraguai, além de enfrentar novamente as guerras civis dos federales provincianos. Sua desconfiança em relação ao Império também se justificaria, pois mesmo tendo organizado uma brigada de voluntários, não foi feito comandante. Insatisfeito Lucas retirou-se para seus negócios particulares.

A prolongada guerra, que de 1867 em diante seria sustentada praticamente pelo Império, foi danosa para o Rio Grande, trazendo problemas econômicos e políticos importantes. O envolvimento de muitos efetivos rio-grandenses ocasionou a desorganização na produção, já que a cavalaria foi recrutada fundamentalmente entre os peões campeiros, como era característico no Prata. Por outro lado, o Rio Grande foi a única província onde se suspenderam as eleições, e a oligarquia regional, muito envolvida com o esforço de guerra, era ainda penalizada com a intervenção das autoridades imperiais nos assuntos internos, ressurgindo as velhas querelas dos homens da fronteira em relação ao centralismo, já que a questão oriental, que lhes interessara, tinha sido resolvida a contento. Como afirma Helga Piccolo,

As críticas foram constantes à atitude do governo imperial exigindo do Rio Grande uma participação ativa através do fornecimento de efetivos para a luta e ao mesmo tempo em que suspendiam as eleiçôes na província. Embora os sul-rio-grandenses obstaculizassem a ação de Solano Lopes no sul (rendição de Estigarríbia) a guerra não lhes dizia respeito. ${ }^{79}$

Esta situação condicionaria um predomínio crescente dos liberais no Rio Grande do Sul, criando no futuro incompatibilidades com os gabinetes conservadores ou com os presidentes provinciais nomeados pelo Império. Esta hegemonia dos liberais no extremo sul seria reforçada pelo prestígio adquirido pelo general Manoel Luís Osório durante a guerra, tornando-se assim o principal representante dos riograndenses. Nos últimos anos do Império, cresceu a importância na Corte dos liberais sulinos, e os republicanos do Rio Grande se originaram de setores desvinculados da economia pecuária; isso traria peculiaridades ao Rio Grande do Sul durante a República Velha.

A Guerra do Paraguai se inscrevera ainda numa sequência de lutas no Rio da Prata, onde se afirmava o papel dos chefes rio-grandenses como "senhores guerreiros"; por conta disto, eram ciosos das 
suas prerrogativas e capazes para buscarem soluções próprias quando em desacordo com as instituições nacionais. Eles brigaram na Cisplatina, na Guerra dos Farrapos, na campanha contra Oribe e Rosas, e também Guerra da Tríplice Aliança; esta longa trajetória nos conflitos platinos deu-lhes a convicção de que podiam sempre preservar seus interesses privados manu militari.

\section{Conclusão}

Afinal, a Guerra do Paraguai favoreceu a consolidação dos Estados nacionais na América do Sul? A existência de um inimigo externo motivou a coesão interna dos países envolvidos no conflito? Os aspectos da política platina aqui levantados apontam para uma resposta negativa: a guerra prolongou as disputas internas e externas das "regiōes-províncias" trazendo mais dificuldades na formação dos Estados-nações.

As disputas entre unitarios e federales na Confederação Argentina, apesar dos esforços de Bartolomé Mitre para interromper o longo ciclo das guerras civis, seriam reabertas no início da Guerra do Paraguai, com rebeliões brotando por todo país. A submissão de Urquiza - principal chefe federal - ao projeto de Mitre, não foi capaz de impedir os conflitos no litoral, marcado pelas deserçôes em massa dos recrutados e comprometendo o seu prestígio; o corolário disso seria o assassinato de Urquiza pelos seus próprios lugares-tenentes. Sua negativa em agregar os federales provincianos não obstaculizou também a fulminante ação da montonera de Felipe Varela, obrigando o virtual abandono dos argentinos da guerra no Paraguai para resolver a questão interna.

Também o Uruguai, onde os colorados tinham o beneplácito das potências vizinhas, não alcançou a ordem interna a partir da luta contra o inimigo externo. As divergências entre colorados e blancos se acirraram pela guerra civil que antecedeu e foi uma das principais causas do grande conflito, e se manifestaram dramaticamente no assassinato quase simultâneo dos principais líderes dos partidos tradicionais, Flores e Berro. Ao invés de estabilidade política, o Estado Oriental mergulharia numa situação crônica de guerras civis, apenas interrompidas pela férrea ditadura militar de Latorre, e o caudilhismo perduraria até a virada do século.

No caso do Rio Grande do Sul manteve-se sua trajetória como fator de instabilidade para o Império. Os chefes sulinos participaram intensamente dos assuntos platinos, especialmente das questóes da Banda Oriental. Numa sequência de eventos que passa pela Cisplatina, pela insurreição farroupilha e pela campanha contra Oribe e Rosas no início dos anos cinquenta, as ações bélicas dos rio-grandenses no Uruguai provocaram intervenções não desejadas do Império, que acabariam redundando na Guerra do Paraguai. Penalizados pelos custos econômicos e políticos do conflito, a guerra não atenuou sentimentos de repúdio à centralização, e ratificou a postura dos "senhores guerreiros" de resistência aos desígnios imperiais.

\section{Notas}

${ }^{1}$ HOBSBAWM, p. 28.

${ }^{2}$ CARMAGNANI, p. 79.

${ }^{3} \mathrm{O}$ litoral é constituído pelas províncias banhadas pelos tributários das bacias dos rios Paraná e Uruguai: já o eram, antes da guerra, as atuais Corrientes, Entre Rios, Santa Fé e parte do Chaco; depois, com territórios tomados ao Paraguai foram incorporadas Misiones, Formosa e o restante do Chaco.

${ }^{4}$ CHIARAMONTE, p. 27.

${ }^{5}$ ZALAZAR, p. 81.

${ }^{6}$ Tratado Uruguay-Corrientes. SENADO DE LA REPÚBLICA ORIENTAL DEL URUGUAY. Tratados y Convenios Internacionales suscritos por el Uruguay en el periodo Mayo de 1830 a Diciembre de 1870. Montevideo: Secreteria del Senado Documentacion y Antecedentes Legislativos, 1993 (Tomo I), p. 18-21.

${ }^{7}$ Tratado de Corrientes. Biblioteca Nacional (BN). Coleção Visconde do Rio Branco.

${ }^{8}$ Convenio de Paysandu. Id. Ibid.

${ }^{9}$ LYNCH, p. 309.

${ }^{10}$ Archivo General de la Nación (AGN). Correspondencia. Fondo de Justo José de Urquiza. Tomo 18, fl. 323. 
${ }^{11}$ Id. ibid., fls. 334-5.

${ }^{12}$ Id. ibid., fls. 327-8.

${ }^{13}$ VASCONCELOS, p. 77.

${ }^{14} I d$., p. 76.

15 Tratado de Alianza Uruguay - Brasil - Entre Ríos e Artículo Adiconal. SENADO DE LA REPÚBLICA ORIENTAL DEL URUGUAY, op. cit., p. 25-29 e 50-55.

${ }^{16}$ Convenio de Paz entre la Confederación Argentina y el Gobierno de Buenos Aires. In: AUZA, Néstor Tomás. Documentos para la Enseñanza de la Historia Argentina 1 (1852-1890). Buenos Aires: Pannedille, 1970, p. 70-73.

${ }^{17}$ A extensa correspondência entre o general Paunero, encarregado das operações levadas a cabo para conter Peñaloza, comprova a importância que Mitre, contrariamente aos liberais mais extremados, dava para cooptação do caudilho riojano ao seu projeto nacional. Archivo de Mitre (AM), Tomo XI, no 2555-2685.

${ }^{18}$ AGN, Correspondencia, Fondo de Justo José de Urquiza. Tomo 252, no 70, Tomo 256, no 101 e Tomo 259 , no 270.

${ }^{19}$ THOMPSON, p. 24-25.

${ }^{20} I d$., p. 46.

${ }^{21}$ LYNCH, p. 310-311.

22 POMER, 1981, p. 274.

${ }^{23}$ BETHELL, p. 25-26.

${ }^{24}$ AGN, Correspondencia, Fondo de Justo José de Urquiza. Tomo 271, no 395-8.

${ }^{25}$ MUSEO MITRE (AM). Correspondencia Mitre-Urquiza (1860-1868). Buenos Aires: Fundacion Banco de la Província de Buenos Aires, 1984, p. 101.

${ }^{26}$ Id. ibid., p. 103.

${ }^{27}$ THOMPSON, op. cit., p. 58.

${ }^{28}$ Id., p. 59-60.

${ }^{29}$ Há uma profusa correspondência de Osório para Urquiza neste sentido. AGN, Correspondencia, Fondo de Justo José de Urquiza. Tomo 271.

${ }^{30} I d$. Tomo 278, n. 333.

${ }^{31}$ Archivo Historico de La Rioja (AHLR), documento n. 75; Archivo Particular del Profesor Dardo de la Vega Díaz, carpeta $21, \mathrm{f} .14$.

${ }^{32}$ AM, Tomo VI, nㅜ 1390 .

${ }^{33}$ Id., ibid., $\mathrm{n}^{-} 1402$.

${ }^{34}$ LUNA, p. 258.

${ }^{35}$ AM, Tomo VI, no 1403 .

${ }^{36}$ PALACIO, p. 522. Da montonera de Jordán fez parte José Hernández, que na luta contra Buenos Aires se inspirou para a maior obra gauchesca: o poema El Gaucho Martín Fierro foi escrito durante o exílio de Hernández na cidade fronteiriça de Santana do Livramento, denunciando a perseguição que os liberais de Buenos Aires exerciam contra os gaúchos, aqueles que para o autor eram os verdadeiros protagonistas da nação.

${ }^{37}$ Tratado Preliminar da Paz. Arquivo Histórico do Rio Grande do Sul (AHRS). Coleção Varela, Diversos. Lata 77, Maço 66.

${ }^{38}$ Como referências pejorativas à sua origem humilde, era comum os adversários referirem-se a Rivera como mulato, maldito mulato, pardo, pardejón,entre outros.

${ }^{39}$ Nome que substituiu a denominação de Províncias Unidas do Rio da Prata.

${ }^{40}$ MINISTÉRIO DAS RELAÇŌES EXTERIORES. A Misão Bellegarde ao Paraguai (1849-1852). Volume I. Rio de Janeiro: Divisão de Documentação, 1966.

${ }^{41}$ Tratado do Império do Brasil e Confederação Argentina. BN, II-32,3,6 no 13.

42 Tratado do Império do Brasil e da República do Paraguai. In: VASCONCELOS, op. cit., p. 327-329.

${ }^{43}$ Tratado de Alianza, Tratado de Extradición de Criminales y Devolución de Esclavos, Tratado de Comercio y Navegación, Tratado de Límites, Convención de Subsídios y Reconocimiento de Deuda. SENADO DE LA REPÚBLICA ORIENTAL DEL URUGUAY, op. cit., p. 30-49.

${ }^{44}$ BETHELL, op. cit., p. 25-26.

${ }^{45}$ POMER, 1981, op. cit., p. 111.

${ }^{46}$ THOMPSON, op. cit., p. 24.

${ }^{47}$ POMER, 1981, op. cit., p. 110. 
${ }^{48}$ THOMPSON, op. cit., p. 25.

${ }^{49} I d$., p. 239.

${ }^{50}$ POMER, 1981, p. 103.

${ }^{51}$ Carta de Rio Branco. Id., p. 40.

${ }^{52}$ Carta de José Berges. Id., p. 46.

${ }^{53}$ LYNCH, op. cit., p. 311-312.

${ }^{54}$ THOMPSON, op. cit., p. 81.

${ }^{55} \mathrm{LYNCH}$, op. cit., p. 313.

${ }^{56}$ Carta de João Manoel de Lima e Silva para Rosas em 14 de outubro de 1836; carta de Bento Gonçalves para Rosas em 16 de dezembro de 1837. AGN, Sala X-1.7.11. Documentos manuscritos: Republica Riograndense.

57 Tratado de Cangüé em 21 de agosto de 1838. AHRS, Coleção Varela. Diversos, Lata 77, Maço 66; Tratado de San Fructuoso em dezembro de 1841. In: SPALDING, Walter. A Revolução Farroupilha. Brasília: UnB, 1982, p. 192-193.

${ }^{58}$ Cartas de João Francisco Regis de 16 de junho a 2 de julho de 1843. AN. Publicaçôes XXXII. Correspondência para Corte dos Encarregados de Negócios em Montevidéu.

${ }^{59}$ Carta de José Gaspar Rodrigues de Francia em 30 de junho de 1839. AHRS, Coleção Varela. CV-4941. Mensagem de Carlos Antonio López em abril de 1842. Id., Diversos, Lata 77, Maço 66.

${ }^{60}$ Cartas de Antônio de Souza Netto. AHRS, Coleção Varela. Lata 68, Maço 41, CV-6393 a CV-6398.

${ }^{61}$ Manifesto de Francisco Pedro de Abreu. In: VASCONCELOS, op. cit., p. 79.

${ }^{62}$ Circular de Domingos José de Almeida. AHRS, Coleção Varela. CV-663.

${ }^{63}$ VASCONCELOS, op. cit., p. 148.

${ }^{64}$ Carta do Marquês de Abrantes. In: POMER, op. cit., p. 111.

${ }^{65}$ Carta de Mármol. In: Id., p. 112.

${ }^{66}$ Carta de Carvalho Moreira. In: Id., p. 114.

${ }^{67}$ Carta de David Canabarro. AHRS, Coleção Varela. CV-3425.

${ }^{68}$ Carta de David Canabarro. Id. ibid., CV-3444.

${ }^{69}$ Carta de David Canabarro. Id. ibid., CV-3445.

${ }^{70}$ Carta de David Canabarro. Id. ibid., CV-3450.

${ }^{71}$ Ofício de David Canabarro. ROSA, p. 69-70. Os grifos são do autor citado.

72 Ofício de David Canabarro. AHRS, Coleção Varela. CV-3509.

${ }^{73}$ Ordem do dia no 21 . Id. CV-3511.

${ }^{74}$ AHRS. Diário do Cel. Manuel Lucas de Oliveira 1864/1865. S. Leopoldo: Edições EST, 1997, p. 43.

${ }^{75}$ Id. ibid., p. 46.

${ }^{76}$ Id. ibid., p. 51.

77 Id. ibid., p. 52.

${ }^{78}$ Id. ibid., p. 54.

${ }^{79}$ PICCOLO, 1979, p. 106.

\section{Referências bibliográficas}

ALONSO ELOY, Rosa et alii. La Oligarquia Oriental en la Cisplatina. Montevideo: Ed. Pueblos Unidos, 1970. BANDEIRA, Luiz Alberto Moniz. O Expansionismo Brasileiro e a Formação dos Estados na Bacia do Prata. Argentina, Uruguai e Paraguai - da Colonização à Guerra da Tríplice Aliança. Brasília: Ensaio/UnB, 1995.

BETHELL, Leslie. Guerra do Paraguai. História e historiografia. In: MARQUES, Maria Eduarda Castro Magalhães (Org.). Guerra do Paraguai 130 Anos Depois. Rio de Janeiro: Relume Dumará, 1995, p. 19-36.

CALÓGERAS, J. Pandiá. A Política Exterior do Império. Volume III: da Regência à Queda de Rosas. Brasília: Câmara dos Deputados/ Cia. Editora Nacional, 1989.

CÁRCANO, Ramón J. Guerra del Paraguay. Buenos Aires: Domingo Viau, 1941.

CARMAGNANI, Marcello. Estado y Sociedad en América Latina. Barcelona: Crítica, 1984. 
CASTRO, Celso; IZECKSOHN, Vitor \& KRAAY, Hendrik. Nova História Militar Brasileira. Rio de Janeiro: FGV / Bom Texto, 2004.

CERVO, Amado Luiz. O Parlamento Brasileiro e as Relaçōes Exteriores (1826-1889). Brasília: UnB, 1981.

CHIARAMONTE, José Carlos. Mercaderes del Litoral. Economia y sociedad en la provincia de Corrientes, primera mitad del siglo XIX. Buenos Aires: Fondo de Cultura Economica, 1991.

COSTA, Wilma Peres. A Espada de Dâmocles - o Exército, a Guerra do Paraguai e a Crise do Império. São Paulo: Hucitec, 1996.

DORATIOTO, Francisco. Maldita Guerra: Nova História da Guerra do Paraguai. São Paulo: Companhia das Letras, 2002.

GRAHAM, Richard. Brasil (1850-1870). In: BETHELL, Leslie (ed.). Historia de América Latina. 6. América Latina independiente, 1820-1870. Barcelona: Cambridge University Press / Editorial Crítica, 1991, p. 378-418.

HOBSBAWM, Eric. Naçōes e Nacionalismo desde 1780. Rio de Janeiro: Zahar, 1991.

IZECKSON, Vitor. O Cerne da Discórdia: A Guerra do Paraguai e o Núcleo Profissional do Exercito Brasileiro. Rio de Janeiro: Biblioteca do Exército Editora, 1997.

LUNA, Félix. Buenos Aires y el País. Buenos Aires: Sudamericana, 1982.

LYNCH, John. Las Repúblicas del Río de la Plata. In: BETHELL, Leslie (ed.). Historia de América Latina. 6. América Latina Independiente, 1820-1870. Barcelona: Crítica, 1991.

OLIVEIRA, Manuel Lucas de. Diário. Porto Alegre: Ediçōes EST, 1997.

PALACIO, Ernesto. Historia de la Argentina 1515-1983. Buenos Aires: Abeledo-Perrot, 1986.

PICCOLO, Helga Iracema Landgraf. A Política Rio-Grandense no Império. In: DACANAL, José Hildebrando \& GONZAGA, Sergius (Orgs.). RS: Economia \& Política. Porto Alegre: Mercado Aberto, 1979.

. Rio Grande do Sul, Província Fronteiriça: Fator de Instabilidade Política no Processo de Independência do Brasil? Anais da XIV Reunião da Sociedade Brasileira de Pesquisa Histórica (SBPH). Salvador: 1994.

POMER, Leon. A Guerra do Paraguai. A Grande Tragédia Rioplatense. São Paulo: Global, 1981. . Cinco Años de Guerra Civil en la Argentina. (1862-1867). Buenos Aires: Amorrortu, 1986.

RODRIGUES, José Honório. O Parlamento e a Consolidação do Império 1840-1861. Contribuiçāo à História do Congresso nacional do Brasil, no periodo da Monarquia. Brasília: Câmara dos Deputados, 1982.

ROSA, Othelo. Vultos da Epopeia Farroupilha. Escorços Biographicos. Porto Alegre, Globo, 1935.

SALA DE TOURON, Lucía \& ALONSO ELOY, Rosa. El Uruguay Comercial, Pastoril y Caudillesco. Tomo II: Sociedad, Politica y Ideologia. Montevideo: Ed. de la Banda Oriental, 1991.

SILVA, José Luiz Werneck da. As Duas Faces da Moeda: a Política Externa do Brasil Monárquico. Rio de Janeiro: Universidade Aberta, 1990.

SPALDING, Walter. A Revolução Farroupilha. Brasília: UnB, 1982.

THOMPSON, George. La Guerra del Paraguay. Asunción: RP ediciones, 1992.

VASCONCELOS, Genserico. História Militar do Brasil. A Campanha de 1851-1852. Rio de Janeiro: Ministério da Guerra, 1941 (2 v.).

ZALAZAR, Roberto. El Brigadier Ferré y el Unitarismo Porteño. Buenos Aires: Pampa y Cielo, 1965. 


\title{
RESUMO
}

O texto destaca as principais incidências politicas dos países envolvidos na Guerra do Paraguai e os principais efeitos pela mesma. Serão tratados os problemas apresentados pelos componentes da Tríplice Aliança: da Confederação Argentina, tanto no litoral quanto no noroeste; do Uruguai, muito dependente das questōes argentinas; do Brasil serão examinadas as questóes relativas ao Rio Grande do Sul, aquela provincia mais diretamente envolvida pela guerra. A hipótese de que a Guerra do Paraguai não foi um fator de consolidação daquelas naçōes que compuseram a Tríplice Aliança obriga a formulação de outra questão: quais seriam as entidades políticas de fato na América platina, e em que medida a guerra a um inimigo externo mantinha ou mesmo reforçava as identidades regionais em contrapartida a uma unidade politica nacional. O presente texto apresenta a hipótese de que eram as "regiōes-provincias" as reais unidades políticas do espaço platino.

Palavras-chave: estados nacionais, "regiōes-provincias", Guerra do Paraguai.

\begin{abstract}
The text highlights the main political incidences of the countries involved in the Paraguayan War and the main effects of the latter. We will treat the problems presented by the constituencies of the Triple Alliance: of the Argentinean Confederation, in the litoral as well as in the northwest; of Uruguay, very dependent of the Argentinean issues; of Brazil, we will examine the issues related to Rio Grande do Sul, the province more directly involved in the war. The hypothesis that the Paraguayan War was not a factor of consolidation of those nations that constituted the Triple Alliance begs the formulation of another question: which were in fact the political entities in the Rio de la Plata region of South America, and how the war against a foreign enemy kept or even reinforced the regional identities in counterpart to a national political unity. The present text presents the hypothesis that the "province-regions" were the real political unities in the Rio de la Plata space.

Keywords: national states, "province-regions", Paraguayan war.
\end{abstract}

